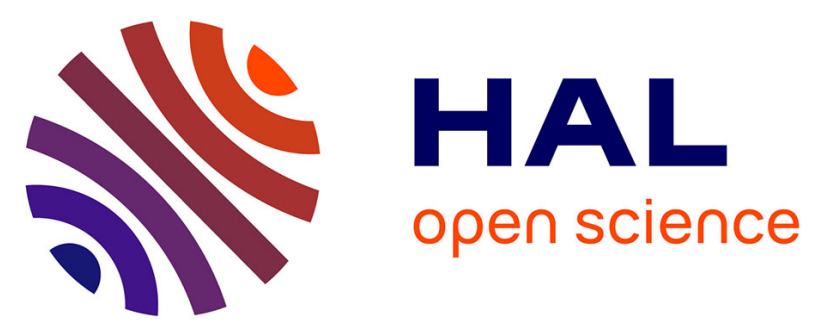

\title{
Why is NanoSIMS elemental imaging of arsenic in seaweed ( Laminaria digitata ) important for understanding of arsenic biochemistry in addition to speciation information?
}

E. Ender, M. Subirana, A. Raab, E. Krupp, Dirk Schaumlöffel, J. Feldmann

\section{To cite this version:}

E. Ender, M. Subirana, A. Raab, E. Krupp, Dirk Schaumlöffel, et al.. Why is NanoSIMS elemental imaging of arsenic in seaweed ( Laminaria digitata ) important for understanding of arsenic biochemistry in addition to speciation information?. Journal of Analytical Atomic Spectrometry, 2019, 34, pp.2295 - 2302. 10.1039/C9JA00187E . hal-02320513

\section{HAL Id: hal-02320513 \\ https://hal-univ-pau.archives-ouvertes.fr/hal-02320513}

Submitted on 9 Dec 2020

HAL is a multi-disciplinary open access archive for the deposit and dissemination of scientific research documents, whether they are published or not. The documents may come from teaching and research institutions in France or abroad, or from public or private research centers.
L'archive ouverte pluridisciplinaire HAL, est destinée au dépôt et à la diffusion de documents scientifiques de niveau recherche, publiés ou non, émanant des établissements d'enseignement et de recherche français ou étrangers, des laboratoires publics ou privés. 


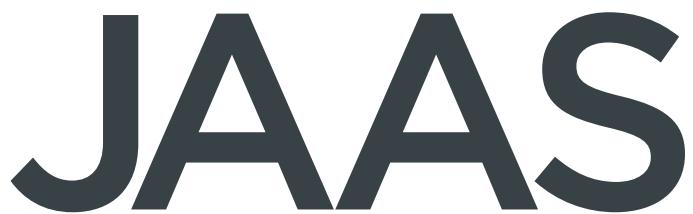

\section{1}

Journal of Analytical Atomic Spectrometry

\section{Accepted Manuscript}

This article can be cited before page numbers have been issued, to do this please use: E. Ender, M. A. Subirana, A. Raab, E. Krupp, D. Schaumlöffel and J. Feldmann, J. Anal. At. Spectrom., 2019, DOI:
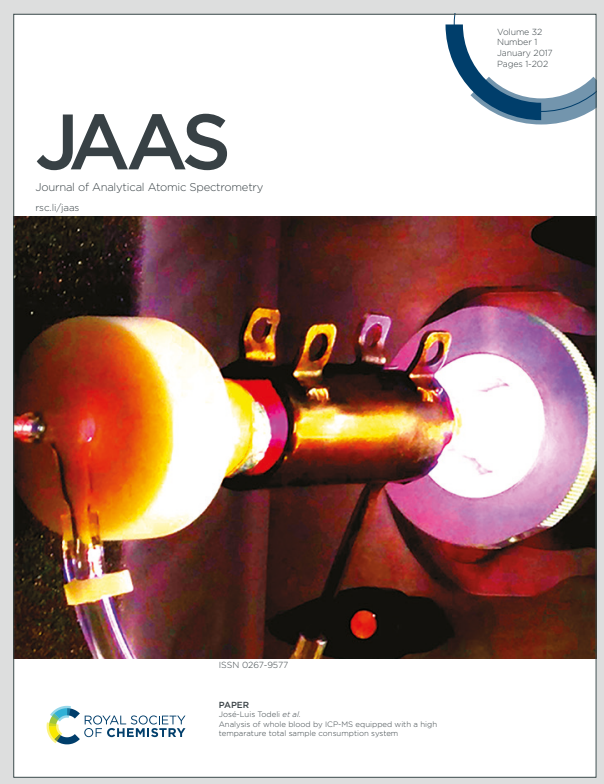

This is an Accepted Manuscript, which has been through the Royal Society of Chemistry peer review process and has been accepted for publication.

Accepted Manuscripts are published online shortly after acceptance, before technical editing, formatting and proof reading. Using this free service, authors can make their results available to the community, in citable form, before we publish the edited article. We will replace this Accepted Manuscript with the edited and formatted Advance Article as soon as it is available.

You can find more information about Accepted Manuscripts in the Information for Authors.

Please note that technical editing may introduce minor changes to the text and/or graphics, which may alter content. The journal's standard Terms \& Conditions and the Ethical guidelines still apply. In no event shall the Royal Society of Chemistry be held responsible for any errors or omissions in this Accepted Manuscript or any consequences arising from the use of any information it contains. 
Why is NanoSIMS elemental imaging of arsenic in seaweed

\author{
E. Ender ${ }^{1}$, M.A.Subirana ${ }^{2}$, A. Raab ${ }^{1}$, E.M. Krupp ${ }^{1}$, D. Schaumlöffel ${ }^{2}$, J. Feldmann $^{1}$
}

7

$8 \quad{ }^{1}$ TESLA, School of Natural and Computing Sciences, University of Aberdeen, Aberdeen AB24

9 3UE, Scotland, UK

${ }^{2}$ CNRS / Université de Pau et des Pays de l'Adour / E2S UPPA, Institut des Sciences

Analytiques et de Physico-Chimie pour l'Environnement et les Matériaux, UMR 5254, 64000

\title{
Abstract
}

Brown seaweed such as Laminaria digitata is known to accumulate arsenic to more than 100 $\mathrm{mg} / \mathrm{kg}$. How the algae can tolerate such high level of arsenic has traditionally been studied by arsenic speciation analysis using HPLC-ICPMS, but the knowledge of its molecular forms has not yet given any answers. Here we demonstrate for the first time that the combination of speciation analysis with high resolution imaging by NanoSIMS and TEM identifies not only the molecular structures of arsenic but also the location of arsenic in cells and cell substructures in a brown seaweed species.

The majority of $117 \mathrm{mg} / \mathrm{kg}$ arsenic in L. digitata fronds was in the form of inorganic arsenic $(53 \%)$ and arsenosugars (32\%) and only $1.5 \%$ of total arsenic as arsenolipids (mainly as AsHC and AsPL). The lateral resolution of $300 \mathrm{~nm}$ and the concentration of arsenic was high enough for the localization of arsenic in the cells of the seaweed using NanoSIMS. The majority of arsenic was found in the cell walls and cell membrane, while the inside of the cell was almost arsenic free, which is not expected if the majority of arsenic species are hydrophilic. The NanoSIMS images questions the integrity of the arsenic species during extraction for the speciation analysis and that inorganic arsenic is unlikely to occur freely in the seaweed. Whether inorganic arsenic and the arsenosugars are bound directly to the polymeric carbohydrates alginates or fucoidans in the seaweed is unclear and needs further investigations. 
The use of analytical atomic spectrometry and in particular ICPMS has been instrumental to identify the molecular forms of arsenic in biological samples over nearly three decades. The complex arsenic biochemistry of more than 100 naturally occurring organoarsenicals in addition to arsenite and arsenate made it necessary to use various HPLC methods coupled to ICPMS and ESI-MS detection in off-line or on-line mode to identify the full spectrum of arsenic species in biological samples even without standards. ${ }^{i}$ However, neither the biosynthetic pathways nor the classification whether these metabolic transformations are detoxification pathways for inorganic arsenic or the formation of beneficial arsenic containing biomolecules have been elucidated; although credible suggestions have recently been made about the arsenosugars. ${ }^{\text {ii }}$ What is missing is the localisation of the arsenic inside the cells in order to answer the above mentioned questions about the biochemistry of arsenic.

It is well known that seaweeds bioaccumulate large concentrations of arsenic from seawater with bioconcentration factor between 1,000 and 100,000. iii Seaweeds and in particular brown macroalgae can reach concentrations up to $200 \mathrm{mg} \mathrm{As} / \mathrm{kg} .{ }^{\mathrm{iv}}$ Most of the arsenic in seaweeds is present as organoarsenicals in the form of arsenosugars (As-sugars), dimethylarsinic acid (DMA) and also in the lipid soluble forms of arsenic containing hydrocarbons (AsHC), fatty acids (AsFA) and phospholipids (AsPL) ${ }^{\mathrm{v}, \mathrm{vi}}$. Only Hijiki spp viiand Laminaria digitata viii,ix seem to contain large amounts of inorganic arsenic.

Here we would like to illustrate the complementary information of using detailed arsenic speciation analysis and mapping of arsenic at sub-cellular level using the brown seaweeds Laminaria digitata as examples to gain more detailed insight into the bioaccumulative behaviour of arsenic especially when the arsenic species are known. Special attention will be given to the differences in the sample preparation procedures. While often the samples are freeze-dried before speciation analysis by HPLC-ICPMS is performed in order to report on concentration relative to dry mass, is it important to have fresh samples available for transmission electron microscope (TEM) and nanoscale secondary ion mass spectrometry (NanoSIMS) analysis which need to be prepared by cryofixation using high-pressure freezing followed by cryo-substitution and resin embedding. This is necessary in order to conserve the cellular ultrastructure and to fix the elements and not distribute them at a sub-cellular level. 


\section{Chemicals and reagents}

All chemicals and reagents were purchased from Sigma-Aldrich (Saint-Quentin Fallavier, France) unless stated otherwise. All solutions, dilutions and preparations were made with water (18.2 $\mathrm{M} \Omega \mathrm{cm}$ ) obtained from a Milli-Q system (Millipore, Bedford, Ma, USA) unless stated otherwise. A $10 \mu \mathrm{L}$ drop of an arsenic ICP Standard, $1000 \mu \mathrm{g} / \mathrm{mL}$ (PlasmaCAL, Villebon-surYvette, France), was dried on a silica wafer and used as standard for mass calibration and mass resolution tuning for As in NanoSIMS.

Chemicals used for extraction were of lab-grade quality (Fisher, UK). Chemicals used for total As determination were of trace-element grade (VWR, UK). HPLC grade methanol (Rathburn, UK), ammonium carbonate (Sigma, UK) and formic acid (mass-spec quality, Fluka, UK) were used for the preparation of HPLC eluents. Nitric acid (70 \% p.a. Fisher, UK) and hydrogen peroxide (32\% Fisher, UK) were used for extraction and digestion. For quantification of Asspecies sodium dimethylarsinic acid (DMA, Chemservice, USA) was dissolved in deionized water and diluted as necessary. Identification of anionic As-species was aided by species standards of DMA, MA (Chemservice, USA), arsenite and arsenate (BDH, UK). Seaweed CRM (ERM-CD-200) a brown algae Fucus vesiculosus was purchased from JRC-Institute for

Reference Materials and Measurements (Geel, Belgium).

Samples

Sampling was conducted at a beach south of Aberdeen, on the east coast of Scotland $(57.139856 \mathrm{~N},-2.051430 \mathrm{~W})$ in November 2018. Freshly washed ashore whole thalli of

Laminaria digitata were harvested.

\section{Sample preparation for NanoSIMS and TEM}

Sample preparation was conducted at the Microscopy and Histology Core Facility at the University of Aberdeen. Two replicates of L. digitata were prepared. Algae discs of $4 \mathrm{~mm}$ diameter were prepared with a biopsy punch and transferred into gold-plated copper specimen carriers filled with hexadecane. High Pressure Freezing was then carried out using a Leica EM ICE (Leica Microsystems, Milton Keynes, UK). For freeze substitution samples were postfixed with $2 \%$ osmium tetroxide $\left(\mathrm{OsO}_{4}\right)$ in acetone and transferred into an automatic freeze substitution system (AFS 2, Leica Mircosystems) following the programme outlined in Supplementary material. This was followed by resin embedding (Spurr's resin, TAAB, UK) 
102

103

104

105

106

107

108

109

110

111

112

113

114

115

116

117

118

119

120

121

122

123

124

125

126

127

128

129

130

131

132

133

134

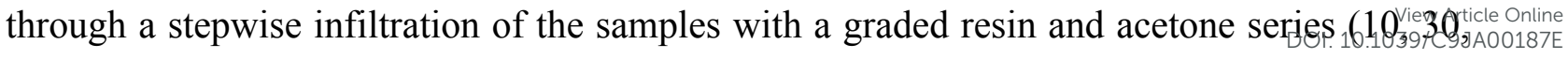
50, 70, and 90\% resin in acetone). Finally, embedded in $100 \%$ resin the samples were polymerized at $60{ }^{\circ} \mathrm{C}$ for at least 24 hours. For TEM analysis, $90 \mathrm{~nm}$ sections were cut from the resin blocks using a diamond knife (Diatome Ltd, Switzerland) on an ultra-microtome (Leica UC6, Leica Microsystems) and placed onto copper grids (TAAB, UK). For NanoSIMS analysis, $300 \mathrm{~nm}$ sections were cut by the same method and placed on silicon wafers (Wafer Solution, Le Bourget du lac, France).

Sample preparation for totals arsenic analysis and speciation analysis

Laminaria digitata fronds were cleaned by scraping and washing off epiphytes and sediment, freeze dried and ground with mortar and pestle to a fine powder. Only the young fronts were analysed.

\section{Extraction of lipophilic arsenic}

Algae $(1 \mathrm{~g})$ were extracted with hexane $(2 \times 5 \mathrm{~mL})$, followed by $\mathrm{CH}_{2} \mathrm{Cl}_{2} / \mathrm{MeOH}(2: 1 \mathrm{v} / \mathrm{v}, 2 \times$ $5 \mathrm{~mL}$ ), and both extracts were evaporated to dryness. For speciation analysis only the $\mathrm{MeOH}$ soluble part of the $\mathrm{CH}_{2} \mathrm{Cl}_{2} / \mathrm{MeOH}$ extract was used.

\section{Extraction of hydrophilic arsenic}

The procedure of Petursdottir et al. ${ }^{\mathrm{x}}$ was used for the extraction. In brief $0.1 \mathrm{~g}$ algae were mixed with $10 \mathrm{~mL}$ of extraction solution (1\% (v/v) nitric acid and $2 \%(\mathrm{v} / \mathrm{v})$ hydrogen peroxide) and heated in a microwave (Mars5, CEM, UK) to $95^{\circ} \mathrm{C}$ for $30 \mathrm{~min}$. The solution was centrifuged and the supernatant used for determination of inorganic arsenic.

\section{Digestion method to determine total arsenic}

Total As was determined after standard microwave digestion with $\mathrm{HNO}_{3} / \mathrm{H}_{2} \mathrm{O}_{2}$ using a Mars5 system (CEM, UK) in solid L. digitata. An ICPMS/MS (Agilent 8800, UK) was used in mass shift mode to determine As on m/z 91 as $\mathrm{AsO}^{+}$.

\section{Determination of hydrophilic and lipophilic arsenic species}

Hydrophilic arsenic species were determined by using anion exchange HPLC-ICPMS/MS. The parameters are given in the supplementary material. The lipophilic arsenic speciation was performed by coupling reverse-phase HPLC simultaneously to ICPMS/MS and ESI-qTOF-MS as described previously ${ }^{\mathrm{xi}}$. The details are given in the supplementary material. 
136 TEM analysis

137 Samples were viewed on the transmission electron microscopes JEM 1400 plus (JEOL, UK) at 138 an accelerating voltage of $100 \mathrm{kV}$ using an AMT UltraVUE camera. The TEM instrument was 139 used to determine quality of sample preparation and for high resolution imaging of sub-cellular structures. Copper grids have been used for sample sections.

\section{NanoSIMS analysis}

143 A NanoSIMS 50L (Cameca, Genneviliers, France) was used for high resolution secondary ion mass spectrometry analysis. A primary $\mathrm{Cs}^{+}$ion source served for the mapping of electronegative elements. Detectors were tuned for carbon $\left({ }^{12} \mathrm{C}_{2}^{-}\right)$, nitrogen $\left({ }^{12} \mathrm{C}^{14} \mathrm{~N}^{-}\right)$, phosphorus $\left({ }^{31} \mathrm{P}^{-}\right)$, sulphur $\left({ }^{32} \mathrm{~S}^{-}\right)$and arsenic $\left({ }^{75} \mathrm{As}^{-}\right)$. As the concentration of As in the sample was relatively low, an As standard was used for mass calibration and mass resolution tuning process. $\mathrm{Cs}^{+}$ions were implanted onto the sample surface in order to increase sensitivity. It should be noted that $\mathrm{N}$ cannot be directly measured using NanoSIMS, therefore carbonnitrogen $\left(\mathrm{CN}^{-}\right)$cluster ions are measured to detect $\mathrm{N}$ in the sample. Images were acquired with a raster size ranging of $35 \mu \mathrm{m}$, divided into 512 x 512 pixels with a dwell time of $10 \mathrm{~ms}$ per pixel. Individual sample sections were located using the NanoSIMS Charged Coupled Device (CCD) camera. The field of view of the CCD camera is about $500 \times 600 \mu \mathrm{m}$ and the optical resolution around $1 \mu \mathrm{m}$, which allows for an overview of the sample and a selection of regions of interest for NanoSIMS analysis.

\section{Results and discussion}

The arsenic concentration in the freeze-dried L. digitata was $117+/-30 \mathrm{mg}$ As/ $/ \mathrm{kg}$ (Table 1), 160 which is in the normal range as reported previously. ${ }^{\text {vii }}$ The accuracy and precision of the total arsenic was evaluated using a seaweed CRM and the recovery was quantitative.

Speciation analysis

164 The speciation of the hydrophilic fraction of arsenic gave the expected distribution of arsenic 165 species, with $53 \%$ of the total arsenic in the form of inorganic arsenic $(62+/-19 \mathrm{mg} \mathrm{As} / \mathrm{kg})$. 166 Arsenosugars in the form of As-sugars (-glycerol, phosphate ester and sulfonate) contributed $16732 \%$ (37 mg As $/ \mathrm{kg}$ ), while DMA was only a minor compound with less than $1 \%$ of total As. 
168 The arsenolipid fraction contributed also only $1.5 \%$ of total arsenic of which the majority View Article Online $16965 \%$ was in the form of arsenosugar containing phospholipids (AsPL) (structures see Figure

170 1). The identification and quantification was done using RP-HPLC-ICPMS/MS coupled

171 simultaneously to ESI-MS. The assignment of the arsenic peaks was achieved by using the

172 retention time as the first criteria, which should coexist with the corresponding protonated

173 mass of the molecular mass (ESI-MS) as can be seen in Figure S1a and S1b (supplementary

174 material). Further evidence for the identification were the accurate masses and MS/MS

175 pattern as described by previously by Raab et al. ${ }^{x i i}$, where the arsenolipid profile of a brown 176 seaweed Saccharina latissima was studied in detail.

Table 1: Total arsenic and hydrophilic arsenic species quantified; total arsenic (iAs), inorganic arsenic determined as arsenate (iAs), Sum of all arsenosugars (As-Sugar). Fractions are given as mass $\%$ of tAs. Errors are given as $+/-\mathrm{SD}$ for $\mathrm{n}=3$.

182

\begin{tabular}{|c|c|c|c|c|c|}
\hline & $\begin{array}{c}\text { tAs } \\
\mathrm{mg} \mathrm{As} / \mathrm{kg}\end{array}$ & $\begin{array}{c}\text { tAs hydro } \\
\text { (hydrophilic) } \\
\text { mg As/kg }\end{array}$ & $\mathrm{mg} \mathrm{As} / \mathrm{kg}$ & $\mathrm{mg} \mathrm{As} / \mathrm{kg}$ & $\begin{array}{l}\text { As-Sugar } \\
\text { (sum) } \\
\text { mg As/kg }\end{array}$ \\
\hline $\begin{array}{c}C R M C D- \\
200^{*}\end{array}$ & $55 \pm 1.0$ & $44 \pm 0.67$ & $0.090 \pm 0.010$ & $8.6 \pm 0.3$ & 32 \\
\hline L. digitata & $117 \pm 30$ & $\begin{array}{c}100 \pm 22 \\
(85.5 \%)\end{array}$ & $\begin{array}{l}62 \pm 19 \\
(53.0 \%)\end{array}$ & $\begin{array}{c}0.93 \pm 0.11 \\
(0.8 \%)\end{array}$ & $\begin{array}{l}37 \pm 3.9 \\
(31.6 \%)\end{array}$ \\
\hline
\end{tabular}

*certified reference value for tAs: $55 \pm 4.0 \mathrm{mg} / \mathrm{kg}$

184

Table 2: Total arsenic and arsenolipids quantified; arsenic containing hydrocarbons (AsHC), 186 arsenosugar containing phospholipids (AsPL).

\begin{tabular}{cccc} 
& $\begin{array}{c}\text { tAs } \text { lipid } \\
\text { (lipophilic) }\end{array}$ & $\begin{array}{c}\text { AsHC } \\
\text { (sum) }\end{array}$ & $\begin{array}{c}\text { AsPL } \\
\text { (sum) }\end{array}$ \\
\hline${ }^{\text {as } \mathrm{mg} \mathrm{As} / \mathrm{kg}}$ & $1.7 \pm 0.22$ & 0.14 & 1.1 \\
$(8.2 \%)^{a}$ & $(65 \%)^{a}$ \\
$\begin{array}{c}\text { Mass \% of } \\
\text { total As }\end{array}$ & $1.5 \%$ & $0.12 \%$ & $0.94 \%$ \\
\hline
\end{tabular}


<smiles>[R]O[C@H]1O[C@H](C[As](C)(C)=O)[C@@H](O)[C@H]1O</smiles><smiles>[R]CSO</smiles>

190

191

Figure 1: generic structures of major organoarsenic compounds in L. digitata: arsenosugar (As-sugar; left), arsenosugar containing phospholipid (AsPL; right)

Table 3: identified As-lipids and their concentration using the ICPMS signal and compoundindependent quantification $(\mathrm{n}=3)$.

\begin{tabular}{|c|c|c|}
\hline detected arsenolipid ${ }^{*}$ & detected accurate mass ${ }^{* *}$ & $\mu \mathrm{g}$ As / $\mathrm{kg}$ algae dry mass \\
\hline (AsFA422) & $\mathrm{C}_{22} \mathrm{H}_{36} \mathrm{AsO}_{3}(\mathrm{~m} / \mathrm{z} 423)$ & $4.2 \pm 0.12$ \\
\hline$(\mathrm{AsHC} 360)$ & $\mathrm{C}_{19} \mathrm{H}_{42} \mathrm{AsO}(\mathrm{m} / \mathrm{z} 361)$ & $71 \pm 6.7$ \\
\hline (AsHC374) & $\mathrm{C}_{20} \mathrm{H}_{44} \mathrm{AsO}(\mathrm{m} / \mathrm{z} 375)$ & $23 \pm 5.3$ \\
\hline (AsHC388 & $\mathrm{C}_{21} \mathrm{H}_{46} \mathrm{AsO}(\mathrm{m} / \mathrm{z} 389)$ & \\
\hline$+\mathrm{AsHC} 402)$ & $+\mathrm{C}_{22} \mathrm{H}_{48} \mathrm{AsO}(\mathrm{m} / \mathrm{z} 403)$ & $18 \pm 2.4$ \\
\hline (AsPL930) & $\mathrm{C}_{43} \mathrm{H}_{84} \mathrm{AsO}_{14} \mathrm{P}(\mathrm{m} / \mathrm{z}$ 931) & $109 \pm 14$ \\
\hline (AsPL944) & $\mathrm{C}_{44} \mathrm{H}_{86} \mathrm{AsO}_{14} \mathrm{P}(\mathrm{m} / \mathrm{z} 945)$ & $69 \pm 11$ \\
\hline (AsPL958) & $\mathrm{C}_{45} \mathrm{H}_{88} \mathrm{AsO}_{14} \mathrm{P}(\mathrm{m} / \mathrm{z} 959)$ & $636 \pm 93$ \\
\hline (AsPL972) & $\mathrm{C}_{46} \mathrm{H}_{90} \mathrm{AsO}_{14} \mathrm{P}(\mathrm{m} / \mathrm{z} 973)$ & $30 \pm 4.4$ \\
\hline (AsPL986) & $\mathrm{C}_{47} \mathrm{H}_{92} \mathrm{AsO}_{14} \mathrm{P}(\mathrm{m} / \mathrm{z}$ 987) & $97 \pm 13$ \\
\hline (AsPL1000) & $\mathrm{C}_{48} \mathrm{H}_{94} \mathrm{AsO}_{14} \mathrm{P}(\mathrm{m} / \mathrm{z} 1001)$ & $14 \pm 1.7$ \\
\hline (AsPL1014) & $\mathrm{C}_{49} \mathrm{H}_{96} \mathrm{AsO}_{14} \mathrm{P}(\mathrm{m} / \mathrm{z} 1015)$ & $119 \pm 18$ \\
\hline
\end{tabular}

*number in parentheses gives the non-protonated molecular mass

**For more information of the As-lipid structures see Raab et al. $2013^{\mathrm{vi}}$

\section{TEM analysis}

The cells of $L$. digitata were imaged with transmission electron microscopy (TEM) and ultrastructures such as the nucleus, Golgi apparatus, chloroplast, and vacuoles were clearly detectable (Figure 2). Most prominent, very thick cell walls were observed which are characteristic for brown algae. These cell walls are adjacent to the cell membrane and consist of an amorphous matrix of alginates and fucoidans with a fibrillary skeleton of cellulose in the inner cell wall. xiii,xiv The amorphous outer cell wall can be also regarded as intercellular material. ${ }^{x v}$ Alginate is an unbranched anionic polysaccharide comprised of two uronic acids: mannuronic acid and guluronic acid. Fucoidans are sulphated fucose-containing 


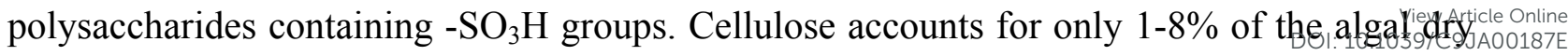
mass, while fucoidans and alginates represent up to $45 \% .{ }^{x v i}$ Moreover, fucoidans play a role in algal cell wall organization and could be involved in the cross linkage of alginate and cellulose. Alginate gives flexibility to algae, serves as a structural support crosslinked by cationic metal ions and bound to proteins, and prevents desiccation. In addition, alginate is involved in the exchange of ions with seawater; it absorbs and retains polyvalent cations at concentrations significantly higher than those in the surrounding water. ${ }^{\text {xvii }}$

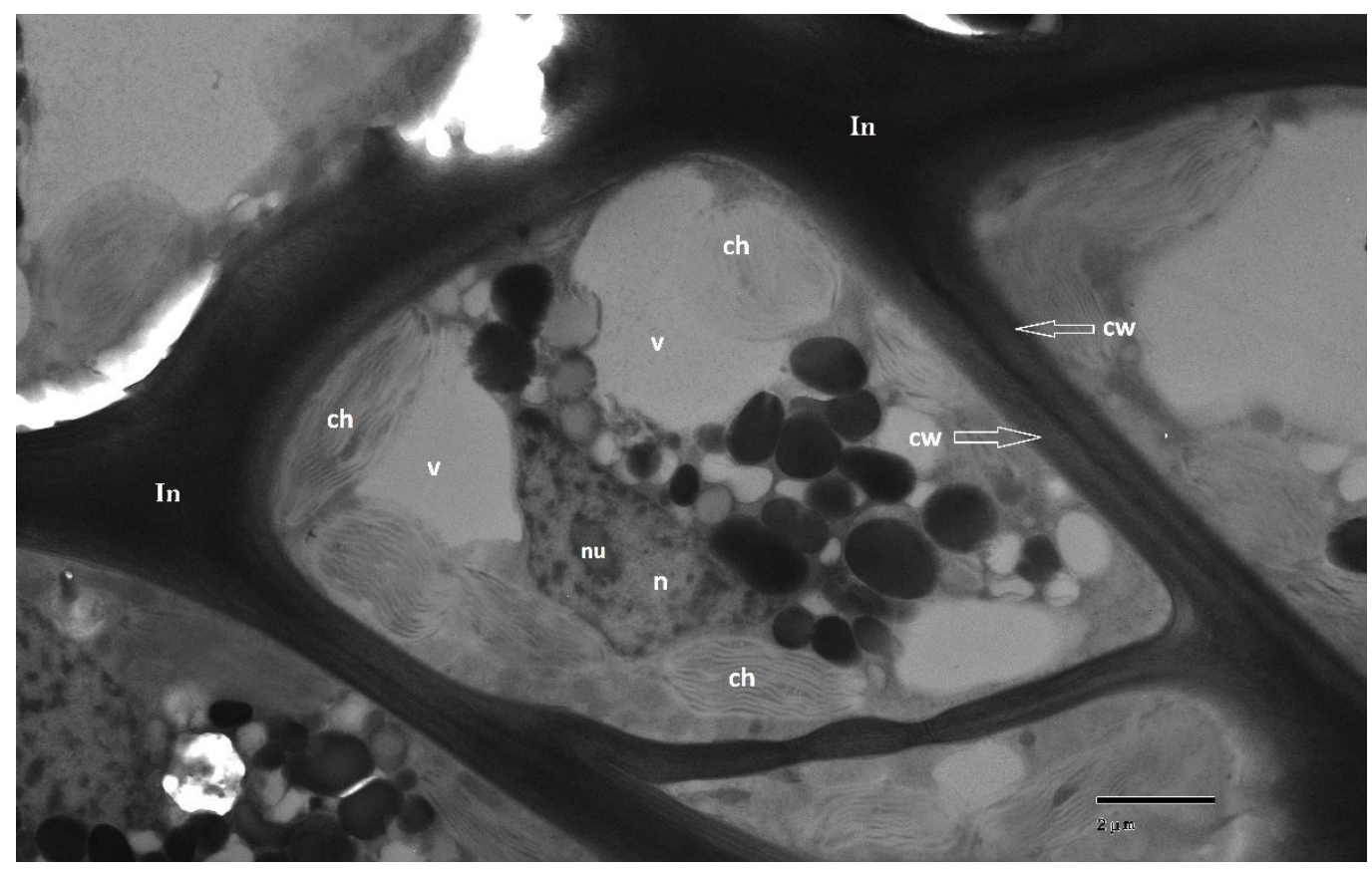

Figure 2. TEM image obtained from $90 \mathrm{~nm}$ section of resin embedded L. digitata cell. Image is of the whole cell including, inner cell wall ( $\mathrm{cw}$ ) and amorphous outer cell wall (intercellular material (In)), cell membrane, vacuoles (v), nucleus (n), nucleolus (nu), chloroplasts (ch)). Bar length is $2 \mu \mathrm{m}$.

\section{Optimization of the NanoSIMS analysis method}

The NanoSIMS analysis method has been optimized with regard to maximal spatial/lateral resolution for sub-cellular imaging and high sensitivity for detection of arsenic at trace level.

For high lateral resolution the $\mathrm{Cs}^{+}$primary ion beam was trimmed using a diaphragm (D1-4) with a circled aperture of $150 \mu \mathrm{m}$ and finally focused with the primary focusing lens (EOP) to its final spot size of about $50 \mathrm{~nm}$ at the sample surface. This lateral resolution was confirmed in our previous work by applying the knife-edge method on a standard sample ${ }^{\mathrm{xviii}}$ and is in agreement with the instrument specifications. In this work, the actual lateral resolution in the 
231

232

233

234

235

236

237

238

239

240

241

242

243

244

245

246

247

248

249

250

251

252

253

254

255

256

257

258

259

260

261

262

263

264

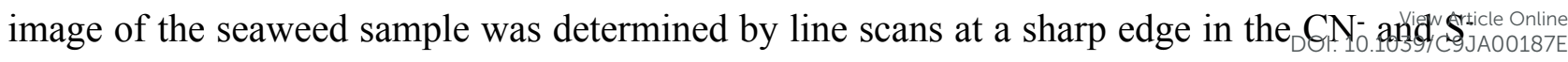
images (Figures $3 \mathrm{ib}$ and 4iia) using the $16-84 \%$ criterion (knife-edge method). Depending on the location in the image the actual resolution was about 300 to $400 \mathrm{~nm}$. Note, that in biological samples not only the NanoSIMS primary beam size, but also the structure of the sample as well as the quality of sample preparation which influences the element distribution in the sample structure contributes to the measured lateral resolution. Therefore in biological samples usually a lower resolution is measured than in standards for the knife-edge method. The selected pixel numbers $(512 \times 512)$ for a $35 \mu \mathrm{m} \times 35 \mu \mathrm{m}$ image results in a theoretical pixel size of $68 \mathrm{~nm}$ which is slightly higher than the smallest possible probe size of $50 \mathrm{~nm}$ but largely sufficient in view of the measured actual lateral resolution for mapping subcellular structures in seaweed cells.

An advantage of the NanoSIMS is that it combines high lateral resolution with high sensitivity. In order to accumulate a sufficient number of counts for the detection of trace amounts of arsenic a compromise had to be found between the dwell time of the primary beam per pixel, the number of accumulated image scans (planes), and a reasonable analysis time in which the thin sample section of $300 \mathrm{~nm}$ was not completely consumed. Note that NanoSIMS is a destructive technique where each scan removes sample material. Under optimized conditions a dwell time of $10 \mathrm{~ms}$ per pixel was chosen resulting in an image scan time of about $44 \mathrm{~min}$. A long-term experiment of about $11 \mathrm{~h} 40 \mathrm{~min}$ showed that 16 scans were possible without complete consumption of the sample. However, already accumulation of 5 image scans enabled a sensitive arsenic detection in a reasonable analysis time of about $3 \mathrm{~h} 40 \mathrm{~min}$ while only a part of the sample was consumed.

\section{Sub-cellular elemental imaging}

Figures 3i-iii show high resolution imaging of a L. digitata cell by NanoSIMS. Both, carbon and nitrogen (via $\mathrm{CN}^{-}$detection) mapping display the thick cell walls/intercellular material. The high amount of polysaccharides in these structures explains the intense carbon signal, although the cells are also embedded in a carbon containing resin matrix. The detection of nitrogen in the cell wall could indicate the presence of proteins. Nitrogen mapping showed subcellular structures, especially chloroplasts were clearly visible, probably due to higher protein concentration in the chloroplasts compared to the cytosol.

In Figure 3ii sulphur was mainly found in the thick cell walls. This intense sulphur signal can be related to the presence of fucoidans, the sulphated polysaccharides typically found in 
seaweed cell walls of brown algae such as $L$. digitata ${ }^{x i x}$. Moreover, sulphur was alsa: detedg in the chloroplast which can be explained by sulphur-containing proteins involved in photosynthesis, such as ferredoxin and iron-sulphur clusters.

The phosphorous image is an accumulation of 5 scans. P was detected in concentrated small spots inside the cell which can be related to in $0.5-1 \mu \mathrm{m}$ sized vacuoles, which can be seen as electronically dense sub-cellular structures in the TEM image (Figure 2). In green algae such small vacuoles are known to be acidocalcisomes containing polyphosphate and calcium and

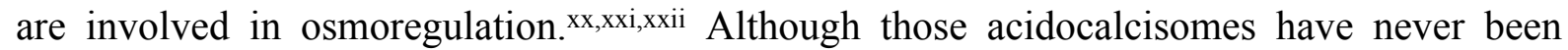
identified in brown algae, they have been found in bacteria to human cells, which make them likely to occur in L. digitata. Moreover, phosphorus was clearly detected in the phospholipid containing cell membranes adjacent to the cell walls.

In Figure 3 iii arsenic was found in a pattern consistent with the cell wall/intercellular material. The image is an accumulation of 5 scans. Figure 3 iii ( $b$ and c) are a colour merge images of the relative distribution of arsenic (white) and nitrogen (red) or phosphorus (blue). It further demonstrates that the arsenic is mainly present in the cell wall with phosphorus outlining the cell membranes and subcellular structures.

Knowing the arsenic speciation in L. digitata, it is not expected that all arsenic would be in the cell membrane, since only a small proportion of arsenic is lipophilic (1.5\%). Almost all arsenic is in the form of either inorganic arsenic or in the form of hydrophilic arsenosugars (together approx. 82\%). No arsenic was detected inside the cells by NanoSIMS in either the cytosol, the vacuoles or acidocalcisomes (their location was indicated by the phosphorus map). Hence, the localisation of arsenic in L. digitata is significantly different to the accumulation of arsenic in rice root cells. ${ }^{\text {xiii }}$ Inorganic arsenic in rice roots is bound mainly to phytochelatins while DMA seemed unbound. ${ }^{\text {xxiv }}$ In contrast brown seaweed with a large proportion of inorganic arsenic (Hijiki spp.) showed no significant amounts of arsenic phytochelatin complexes. ${ }^{\mathrm{xxv}}$ Hence, the lack of arsenic in the cytosol and in particular in the vacuoles of L. digitata is not surprising.

It seems that most arsenic is located in the cell walls containing polysaccharides such as alginate, fucoidan and cellulose. Those alginates are also known to accumulate mono and divalent cations such as $\mathrm{Na}^{+}, \mathrm{K}^{+}, \mathrm{Ca}^{2+}$, but also $\mathrm{Zn}^{2+}$ and $\mathrm{Cu}^{2+}$ xiv Arsenic however in its inorganic forms is either neutral $\left(\mathrm{As}(\mathrm{OH})_{3}\right)$ or anionic $\left(\mathrm{HAsO}_{4}{ }^{2-}\right)$ and will not bind to the alginates in the same way. So far it is not known if arsenate or arsenite bind to either alginates 
299

300

301

302

303

304

305

306

307

308

309

310

311

312

313

314

315

316

317

318

319

320

321

322

323

324

325

326

327

328

329

330

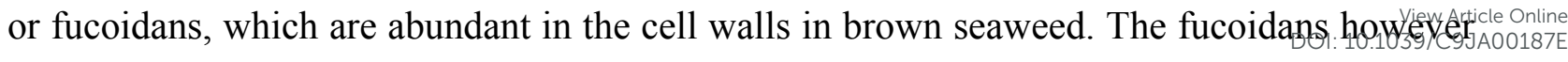
bind sulphate as sulfuric acid ester. If arsenic binds as arsenate to the carbohydrate in a similar way is unclear. The resulting arsenic acid esters would be very unstable and will quickly hydrolyse and form again inorganic arsenic. ${ }^{x x v i}$ It has been noted that not only AsHC and AsPL can be extracted, some unstable arsenic species have also been extracted with DCM/MeOH. A significant part of the extract eluted however in the void of a reverse phase HPLC method. This was likely to be attributed to unstable non-polar arsenolipids as shown before. ${ }^{\text {xxvii }}$ Arsenic acid esters would quickly hydrolyse to inorganic arsenic during the sample preparation step.

Although the binding of arsenite or arsenate to the constituents of the cell wall and membrane is unclear, the accumulation of arsenate into the cell wall is however mechanistically conceivable. The arsenic accumulation into brown seaweed depends on the salinity and hence also on the arsenic concentration in the seawater. ${ }^{\text {xxviii }}$ Arsenate might directly accumulate from seawater or indirectly when it is taken up through phosphate transporters and then excreted as arsenite. Efflux of arsenite is well known, while the efflux of arsenate has only recently been suggested to occur as well. .xix $^{\text {. }}$

The accumulation of arsenosugars in the cell wall is however more difficult to understand. Since no arsenosugars have been found in seawater so far, the accumulation of these arsenic species need to come from biotransformation reactions either directly within the macroalgae or from bacteria on the surface of the seaweeds. ${ }^{\mathrm{xxx}}$ If the arsenosugars are transported through the cell membrane into the cell wall, then certain transporters which excrete those compounds need to exist. Otherwise, the arsenosugars could be linked to the alginates which are produced in the Golgi apparatus and then directly incorporated into the carbohydrate structure. They might bind directly to the carbohydrates via the alcohol groups or the sulfonate (major arsenosugar in $L$. digitata is the AsSugar- $\mathrm{SO}_{3}$ ). These compounds again would be rather unstable in water and hydrolyse quickly. The fact that no hotspot inside the cell which could be assigned to the Golgi apparatus has been found, indicates that the arsenic transformation inside the cell needs to be fast. Alginate generation is taking place within 20 minutes. This would explain that the cytosol and the sub-cellular structures inside the cell are virtually arsenic free. 


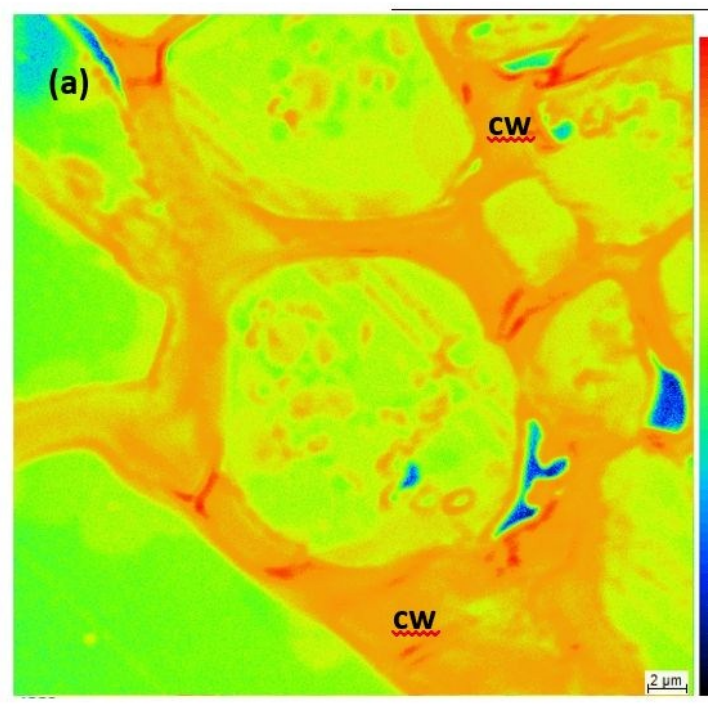

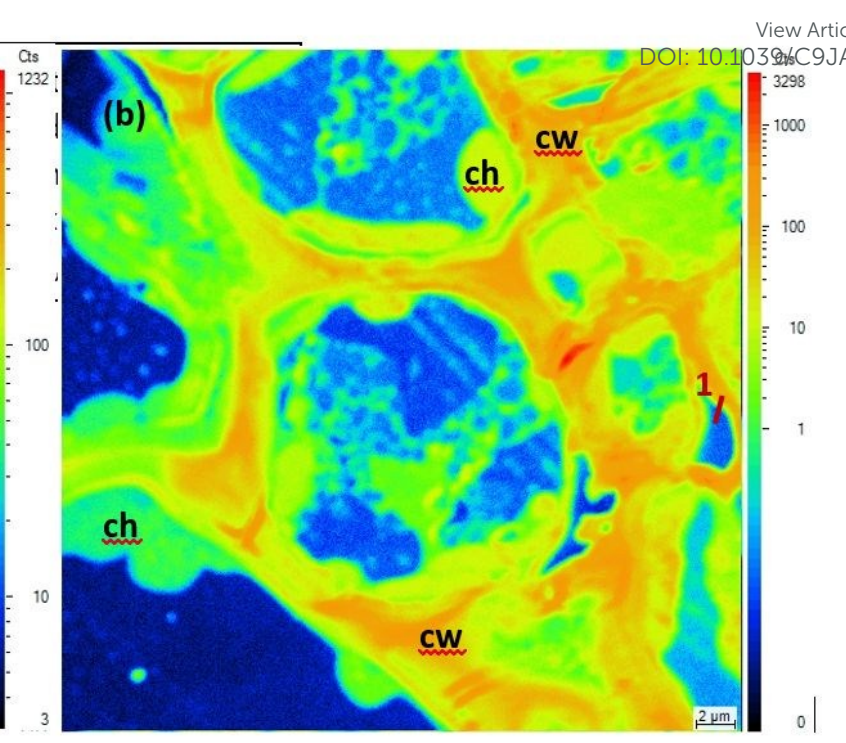

View Article Online

333 digitata cells by NanoSIMS obtained from a $300 \mathrm{~nm}$ resin section. Both images display the 334 thick cell walls (cw). N mapping (b) shows subcellular structures, e.g. chloroplasts (ch), line 335 scan 1 (red line) resulted in a measured lateral resolution of $305 \mathrm{~nm}$. NanoSIMS images were 336 obtained with an $\mathrm{Cs}^{+}$plasma primary ion source for detection of negative secondary ions: $35 \mathrm{x}$ $33735 \mu \mathrm{m}^{2}$ field of view images; 512 x $512 \mathrm{pixel}$; dwell time $10 \mathrm{~ms} /$ pixel; total image acquisition 338 time approx. 44 min.
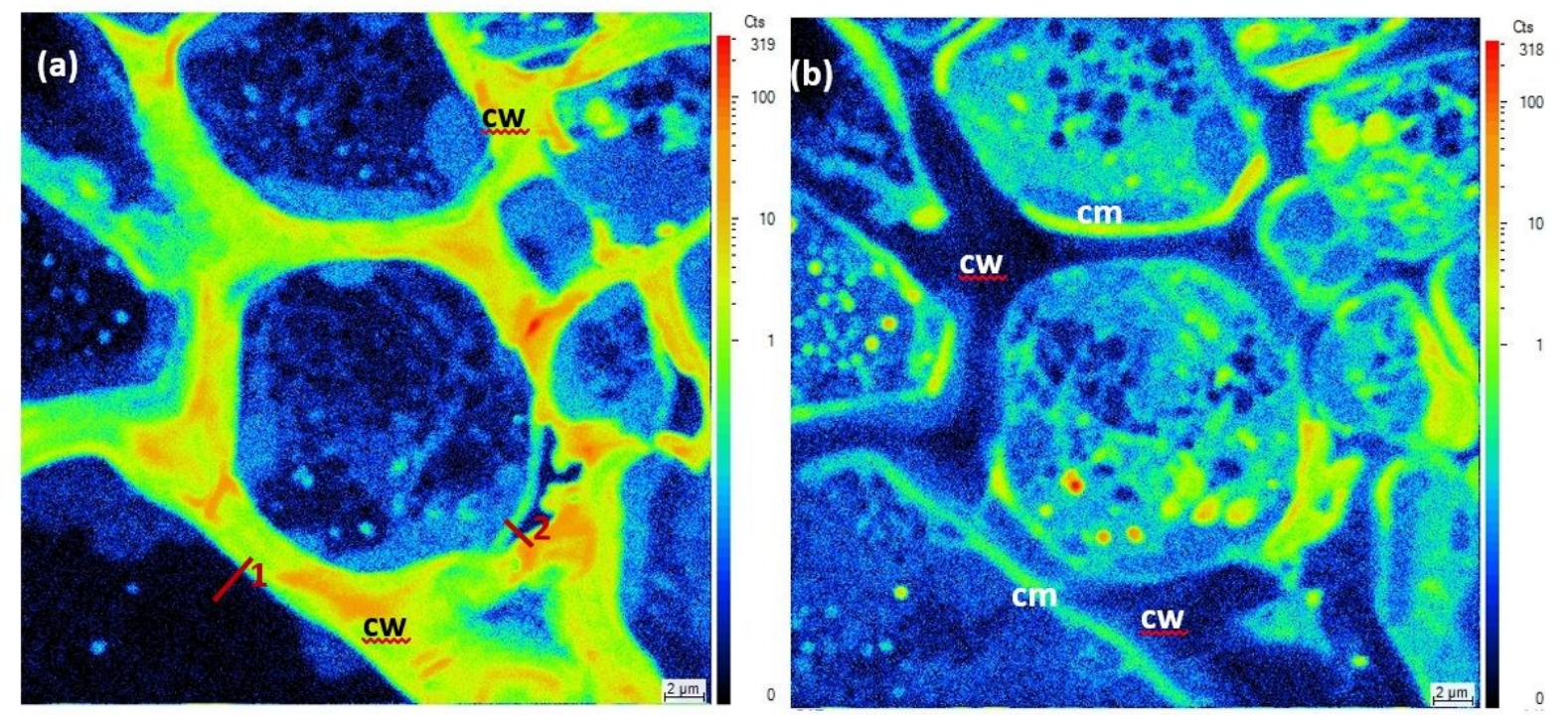

340 Figure 3ii. High resolution imaging of S (a) and P (b) in L. digitata cells by NanoSIMS 341 obtained from a $300 \mathrm{~nm}$ resin section. $\mathrm{S}$ is mainly concentrated in the thick cell 342 walls/intercellular material (cw). P is more concentrated in spots inside the cells as well as in 343 the cell membrane (cm) adjacent to the cell wall. Line scans 1 and 2 (red lines) resulted in 344 measured lateral resolutions of $433 \mathrm{~nm}$ and $295 \mathrm{~nm}$, respectively. NanoSIMS images were 


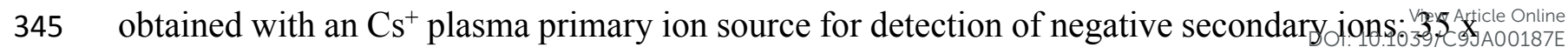
$34635 \mu \mathrm{m}^{2}$ field of view images; 512 x 512 pixel; dwell time $10 \mathrm{~ms} /$ pixel; total image acquisition 347 time approx. $44 \mathrm{~min}$.
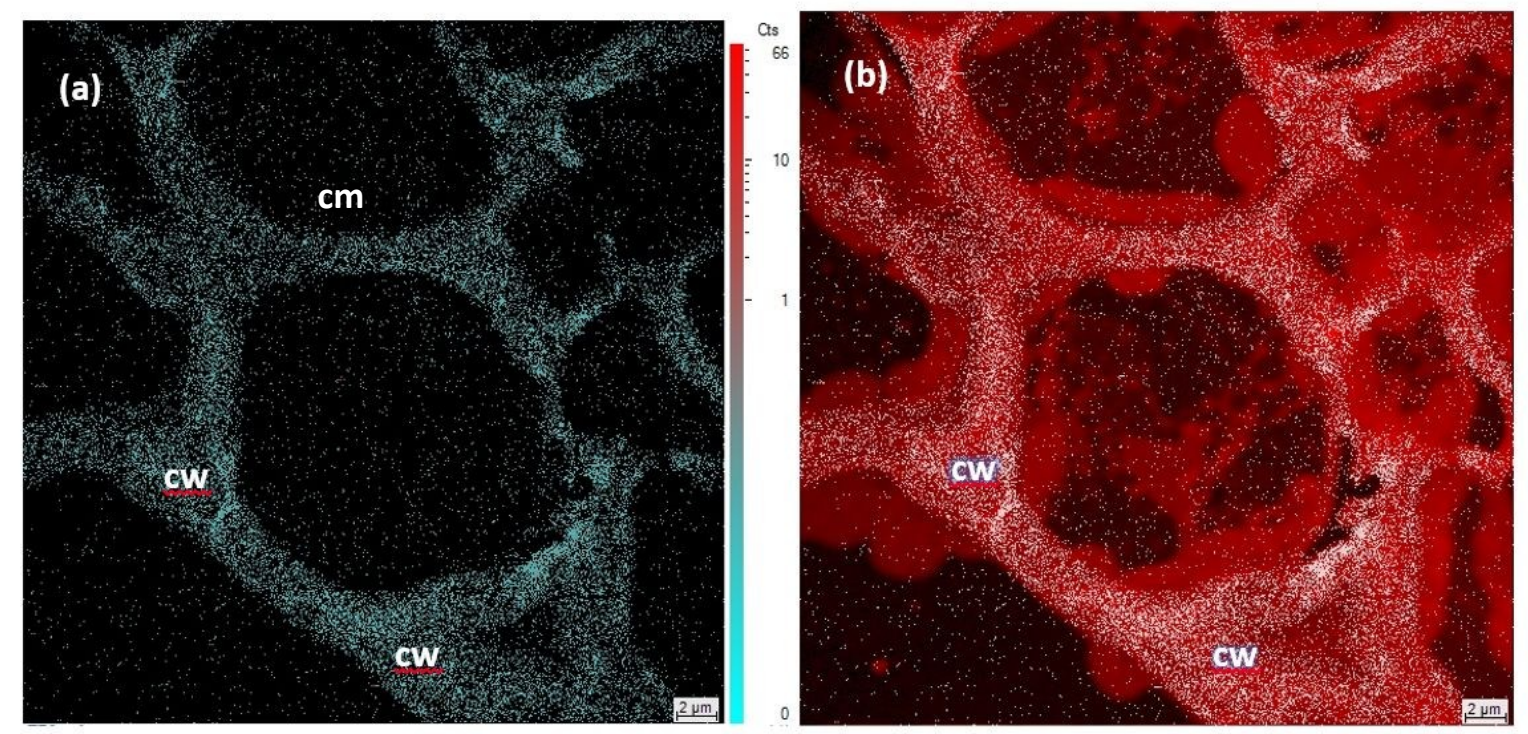

348

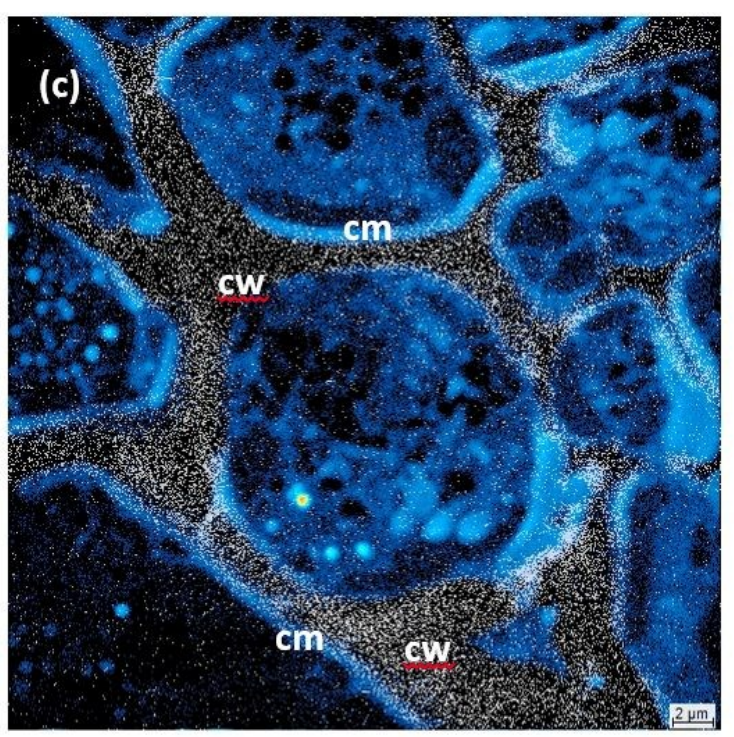

350 Figure 3iii. High resolution accumulated imaging of As (a) in L. digitata cells and two colour 351 merge images that shows the relative distribution of As (white) and $\mathrm{N}$ (red) localisation (b) as 352 well as As (white) and P (blue) localisation (c) by NanoSIMS obtained from a $300 \mathrm{~nm}$ resin 353 section. As was mainly found in the cell wall/intercellular material (cw) and to a much lesser 354 extend in the cell membrane $(\mathrm{cm})$. NanoSIMS images were obtained with an $\mathrm{Cs}^{+}$plasma 355 primary ion source for detection of negative secondary ions: 35 × $35 \mu \mathrm{m}^{2}$ field of view images; 512 x 512 pixel; dwell time $10 \mathrm{~ms} /$ pixel; total image acquisition time approx. $44 \mathrm{~min}$. 
358

359

360

361

362

363

364

365

366

367

368

369

370

371

372

373

374

375

376

377

378

379

380

381

382

383

It has been speculated that arsenosugars are intermediates in the formation of arsenglipids Sivew as AsPL.i But when arsenosugars accumulate in large quantities in the cell wall, then the biosynthesis to AsPL needs to take place there as well, which is unlikely. Hence, the localisation of arsenic in the cell wall rather than in the cell membrane indicates that the seaweed can handle certain concentrations of arsenic and has means of excluding the arsenic from the cytosol and other sub-cellular structures within the cell. The biotransformation and kinetics of arsenic in L. digitata are not clear, but the seaweed is able to biotransform quickly the taken up arsenic and transport it outside the cell. This could be an effective detoxification strategy, or the evidence of the utilization of the accumulated arsenic for a purpose, since the cell wall with the gel-like alginates and sulphated fucoidans act often as the first barrier to toxic or unwanted chemicals. More fundamental studies are necessary to elucidate the biochemical role of arsenic in seaweed.

In summary the complimentary use of high spatial resolution imaging of elements at a subcellular level in combination of speciation analysis can shed new lights on the role of arsenic in seaweeds. Is the arsenic in the form of inorganic arsenic essential for the algae as suggested elsewhere ${ }^{\mathrm{xxxi}}$ or is the efflux of arsenic in these molecular forms into the intercellular space or the cell wall a successful detoxification strategy? These questions can only be asked if in addition to arsenic speciation also its distribution within a cell and sub-cellular structures is known this however would need a high resolution imaging technique which is capable at the same time to provide speciation information. $\mu$-XANES would have the analytical attributes but its resolution is currently not sufficient to identify subcellular structures.

\section{References}

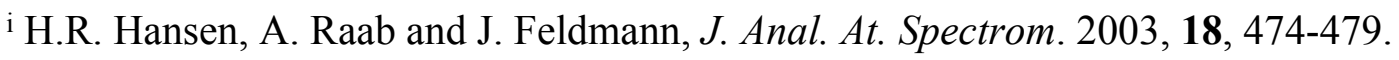

ii X.M. Xue, J. Ye, G. Raber, B.P. Rosen, K. Francesconi, C. Xiong, Z. Zhu, C. Rensing, and Y.G. Zhu, Environ. Sci. Technol. 2019, 53, 634-641.

iii W. Maher and E. Butler, Appl. Organmet. Chem., 1988, 2, 191-214.

iv J. Feldmann and E.M. Krupp, Anal. Bioanal. Chem., 2011, 399, 1735-1741.

${ }^{v}$ S. Garcia-Salgado, G. Raber, R. Raml, C. Magnes and K.A. Francesconi, Environ. Chem., $2012,9,63-66$. 
${ }^{v i}$ A. Raab, C. Newcombe, D. Pitton, R. Ebel, and J. Feldmann, Anal. Chem. 2013, 85, $2817-$ 2824.

${ }^{\text {vii }}$ K. Hanaoka, K. Yosida, M. Tamano, T. Kuroiwa, T. Kaise and S. Maeda, Appl.

Organomet. Chem., 2001, 15, 561-565.

viii J.M. Ronan, D.B. Stengel, A. Raab, J. Feldmann, L. O’Hea, E. Bralatei and E. McGovern. Chemosphere 2017, 186, 17-23.

ix E. Bralatei, K. Nekrosuite, J. Ronan, A. Raab, E. McGovern, E.M. Krupp and J. Feldmann, Microchim. Acta 2017, 184, 1701-1709.

x A.H. Petursdottir, N. Friedrich, S. Musil, A. Raab, H. Gunnlaugsdottir, E.M. Krupp and J. Feldmann, Anal. Met. 2014, 6, 5392-5396.

xi K.O. Amayo, K.O, A.H. Petursdottir, C. Newcombe, H. Gunnlaugsdottir, A. Raab, E. Krupp, and J. Feldmann, Anal. Chem. 2011, 83, 3589-3595.

xii A. Raab, C. Newcombe, D. Pitton, R. Ebel and J. Feldmann, Anal. Chem. 2013, 85, $2817-$ 2824.

xiii S. Schiewer and B. Volesky, Biosorption by marine algae. In: Valdes JJ, editor.

Remediation. Dordrecht, The Netherlands: Kluwer Academic Publishers; 2000.p. 139-69.

xiv T. A. Davis et al., A review of the biochemistry of heavy metal biosorption by brown algae. Water Res. 2003, 37, 4311-4330.

xv W. Mackie and R.D. Preston. Cell wall and intercellular region polysaccharides. In:

W.D.P. Stewart, editor. Algal physiology and biochemistry. Oxford, UK: Blackwell Scientific Publications; 1974. p. 58-64.

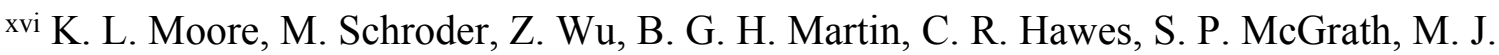
Hawkesford, J. Feng Ma, F.-J. Zhao, and C. R. M. Grovenor, Plant Physiol., 2011, 156, 913924.

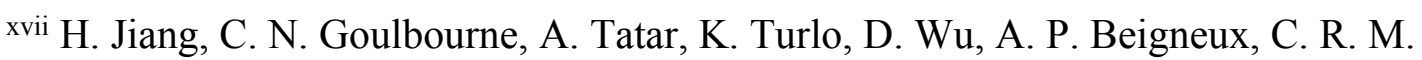

Grovenor, L. G. Fong, and S. G. Young, J. Lipid Res., 2014, 55, 2156-2166.

xviii Malherbe, J., Penen, F., Isaure, M.-P., Frank, J., Hause, G., Dobritzsch, D., Gontier, E., Horreard, F., Hillion, F., Schaumloeffel, D., Anal. Chem. 2016, 88, 7130-7136 xix A. Synytsya, J. Čopíková, W.J. Kim, Y.I. Park. (2015) Cell Wall Polysaccharides of Marine Algae. In: Kim SK. (eds) Springer Handbook of Marine Biotechnology. Springer Handbooks. Springer, Berlin, Heidelberg.

${ }^{x x}$ N. Lander, C. Cordeiro, G. Huang and R. Docamo, Biochem. Sco. Trans. 2016, 44, 1-6.

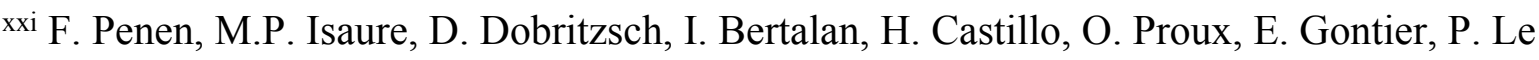


Coustumer and D. Schaumlöffel, Metallomics 2017, 9, 910-923.

xxii F.A. Ruiz, N. Marchesini, M. Seufferheld, Govindjee and R. Docampo, J. Biol. Chem., 2001, 276, 49196-46203.

xxiii K.L. Moore, M. Schroder, E. Lombi, F.J. Zhao, S.P. McGrath, M.J. Hawkesford, P.R. Shewry and C.R.M. Grovenor, New Phytol. 2010, 185, 434-445.

xxiv B.L. Batista, M. Nigar, A. Mestrot, B.A. Rocha, F. Barbosa Jr, A.H. Price, A. Raab and J. Feldmann, J. Exp. Bot., 2014, 65, 1467-1479.

${ }^{x x v}$ B.A. Wood, A.A. Meharg, S. Miyashita, T. Kaise, A. Raab and J. Feldmann, Environ. Chem. 2011, 8, 30-43.

${ }^{x x v i}$ F.H. Westheiner, Science (1987) 235, 1173-1178.

xxvii A.H. Petursdottir, J.R. de Jesus, H. Gunnlaugsdottir and J. Feldmann, J. Anal. At. Spectrom., 2018, 33, 102-110.

xxviii E. Ownsworth, D. Selby, C.J. Ottley, E.Unsworth, A. Raab, J. Feldmann, A.D. Sproson, J. Kuroda, C. Faidutti and P. Bücker, Sci. Tot. Environ., 2019, 685, 259-272.

xxix L.D. Garinski, B.P. Rosen and J. Chen, Environ. Intern., 2019, 126, 585-597.

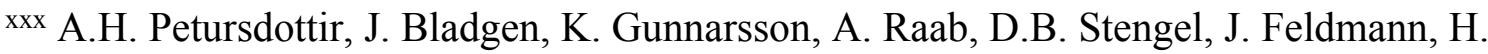
Gunnlaugsdottir, Anal. Bioanal. Chem., 2019, 411, 4973-4985.

xxxi A.H. Petursdottir, K. Fletcher, H. Gunnlaugsdottir, E. Krupp, F. Kuepper, J. Feldmann, Environ. Chem., 2015, 13, 21-33. 


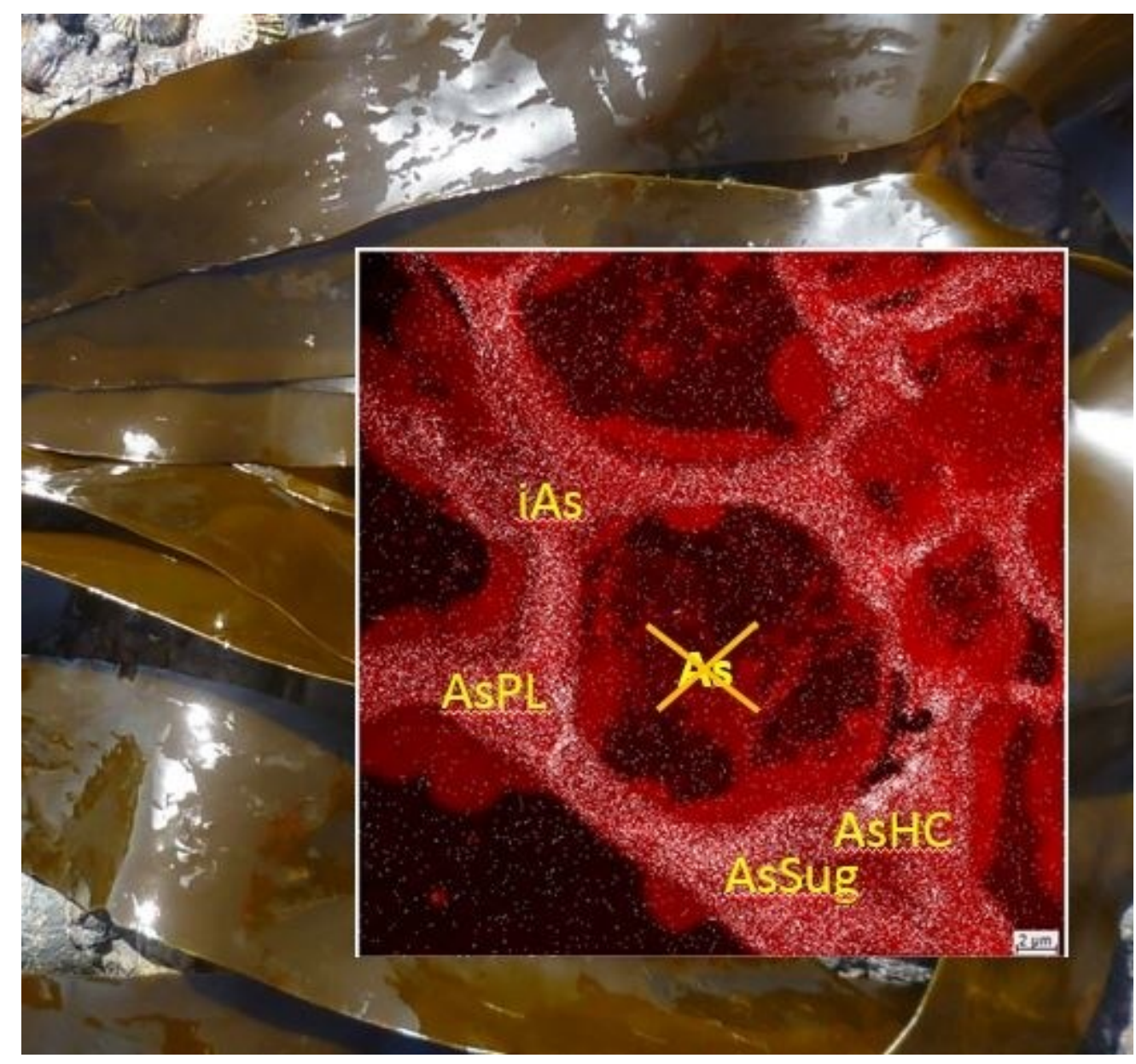

$108 \times 101 \mathrm{~mm}(120 \times 120 \mathrm{DPI})$ 